\title{
TEGANGAN PULLOUT DAN PEREKAAN PERMUKAAN PADA SERAT DAUN PANDAN DURI (PANDANUS TECTORIUS) - RESIN POLYESTER
}

\author{
Achmat Riyanto, Sri Mulyo Bondan Respati* dan Imam Syafa'at \\ Jurusan Teknik Mesin, Fakultas Teknik, Universitas Wahid Hasyim Semarang \\ Jl. Menoreh Tengah X/22, Sampangan, Semarang 50236 \\ *Email: bondan@unwahas.ac.id
}

\begin{abstract}
Abstrak
Dewasa ini perkembangan teknologi yang semakin maju menyebabkan kebutuhan material komposit semakin meningkat, salah satunya teknologi material komposit berpenguat serat alam, serat daun pandan duri berpotensi untuk dijadikan sebagai bahan baku material komposit. Penelitian ini bertujuan untuk mengetahui kekuatan tarik dan foto mikro serat daun pandan duri dengan perlakuan perendaman air laut. Pengujian pull-out juga dilakukan untuk mengetahui tegangan geser serat dengan matrik resin polyester. Serat daun pandan duri yang direndam kedalam air laut, dengan variasi waktu 0, 1, 2, 3, dan 4 minggu. Hasil yang diperoleh dari uji tarik serat tunggal menunjukkan bahwa pada perendaman selama 2 minggu memiliki nilai kekuatan tarik yang optimal sebesar 28,65 Mpa, hal ini juga terbukti dari hasil foto mikro serat yang menunjukan kepadatan sub celahnya. Sedangkan kekuatan tarik serat tanpa perlakuan perendaman dan perendaman selama 1, 3, dan 4 minggu berturut-turut adalah 22,57 MPa, 24,43 MPa, dan 18,96 MPa. Kemudian pada pengujian pull out nilai tegangan geser tertinggi sebesar 1,33 MPa lebih tinggi dibanding tanpa perlakuan perendaman dan perendaman air laut 1, 3, dan 4 minggu berturut-turut yaitu sebesar 0,09 MPa, 1,11 MPa, 1,21 MPa, dan 1,07 MPa. Dari hasil penelitian yang dilakukan, serat daun pandan duri mempunyai kompatibilitas yang baik dengan resin polyester setelah diberi perlakuan perendaman air laut
\end{abstract}

Kata kunci: serat daun pandan duri, resin uji pull-out, kompatibilitas

\section{PENDAHULUAN}

Pohon pandan duri sudah lama dikenal oleh masyarakat pesisir Pantai sebagai pohon yang banyak mempunyai manfaat. Hampir semua bagian pohon ini dapat dimanfaatkan, seperti bagian daun, akar, serabut dan buah. Salah satu bagian yang paling banyak dimanfaatkan adalah daunnya yaitu sebagai bahan baku anyaman tikar dan topi (Santos, 1998)

Perlakuan perendaman pada serat merupakan proses untuk menghilangkannya komponen penyusun serat yang kurang efektif dalam menentukan kekuatan antar muka. Pemilihan air laut dikarenakan air laut sangat melimpah dan memiliki susunan $\mathrm{NaCl}$ yang tinggi dan $\mathrm{NaCl}$ bersifat sulit untuk bersenyawa dengan organisme yang lain yang berfungsi sebagai pengawet alami (Estiasih, 2009).

Kualitas ikatan antar permukaan menjadi lebih tinggi dengan durasi tambahan dari perendaman air laut. Yang terbaik permukaan serat dan matrik dilihat pada komposit dengan perendaman berdurasi 4 minggu, yang ditunjukkan dengan hilangnya celah antara serat dan matrik (Mardin, 2014).

Tujuan dari penelitian ini adalah untuk Mengetahui pengaruh waktu perendaman serat daun pandan duri pada air laut terhadap kekuatan tarik dan struktur mikro juga mengetahui tegangan geser dan kerapatan serat tunggal daun pandan duri dengan resin.

\section{Serat daun pandan duri}

Serat daun pandan duri adalah serat alami alternatif dalam pembuatan komposit, yang pemanfaatannya terus dikembangkan agar dihasilkan komposit yang lebih sempurna dikemudian hari. Serat daun pandan didapat dengan cara membusukkan daun pandan sehingga serat dapat dengan mudah dipisahkan dengan bagian daun yang lain. Serat daun pandan yang digunakan pada penelitian berfungsi sebagai bahan penguat pada pembuatan komposit. Massa jenis serat daun pandan yaitu 0,96 gr/cm3 (Salahudin, 2012). Komposisi kimia serat pandan ditunjukan pada Tabel 1.

Tabel 1 Komposisi kimia serat pandan (Winarni dan Waluyo, 2006).

\begin{tabular}{cc}
\hline Komposisi Kmia & Kandungan $(\%)$ \\
\hline Lignin & $18-22$ \\
Selulosa & $83-88$
\end{tabular}


Holoselulosa

Air

$7,88-9,14$

\section{Air laut}

Air laut sangat melimpah dan memiliki susunan $\mathrm{NaCl}$ yang tinggi dan $\mathrm{NaCl}$ bersifat sulit untuk bersenyawa dengan organisme yang lain yang berfungsi sebagai pengawet alami. (Estiasih, 2009)

Matasina dkk., (2014) menjelaskan mengenai pengaruh lama perendaman yang menyatakan bahwa semakin lama waktu perendaman atau semakin tinggi penyerapan air yang digunakan maka regangan komposit akan semakin meningkat atau berbanding terbalik dengan tegangan, akibat gaya yang diterima atau beban yang diterima sehingga membuat komposit menjadi getas dan mudah untuk patah.

Menurut Fattah dkk.(2013) mengenai lama waktu perendaman menjelaskan semakin lama jangka waktu yang diperlukan untuk merendam kayu, akan membuat kayu itu semakin rendah kekuatannya bila dibandingkan dengan kekuatan kayu sebelum direndam. Hal ini disebabkan karena sel-sel penyusun kayu akan semakin renggang dan akhirnya terurai bila kayu direndam dalam jangka waktu yang semakin lama. Kondisi hubungan antar sel kayu yang demikian akan menurunkan kekuatan kayu.

\section{Resin thermoset jenis polyester}

Resin polyester adalah resin cair dengan viscositas rendah, mengeras pada suhu kamar dengan penggunaan katalis tanpa menghasilkan gas sewaktu pengetesan seperti banyak resin lainnya.

Bahan tambahan utama adalah katalis (Hardener). Jenis katalis untuk resin polyester yaitu Metyl Etyl Keton Peroksida (MEKPO). Katalis berfungsi untuk mempercepat proses pengerasan cairan resin (curing). Semakin banyak katalis reaksi curing akan semakin cepat, tetapi kelebihan katalis juga akan menimbulkan panas pada saat curing bisa merusak produk yang akan dibuat yaitu menjadikan bahan komposit getas atau rapuh. Oleh karena itu pemberian katalis dibatasi $1 \%$ samapi $2 \%$ dari berat resin. (Nugraha, 2015)

\section{Kekuatan tarik serat tunggal}

Kekuatan tarik serat dapat diperoleh dari pengujian tarik yaitu pengujian yang umum dilakukan terhadap material teknik untuk mendapatkan karakteristik deformasi kekuataan dari material. Pengujian serat tunggal dilakukan sesuai standar ASTM D3379. Kekuatan tarik dihitung menggunakan persamaan 1: (Smith, 1986)

$\sigma=\frac{F}{A o}$

dengan $\sigma$ adalah kekuatan tarik serat yang dihasilkan beban tarik (P) dibagi luasan penampang (Ao). Regangan dihitung dengan perubahan panjang $(\Delta L)$ dibagi panjang awal (Lo). (Nugraha, 2015)

$\varepsilon=\frac{\Delta L}{L o} \times 100 \%$

\section{Kekuatan geser interfacial}

Serat dengan diameter $\mathrm{d}$ yang tertanam suatu matrik dan dalam kondisi tertarik lepas seperti ditunjukkan pada gambar. Kekuatan geser interfacial sangat tergantung pada mutu ikatan antara serat/matrik.

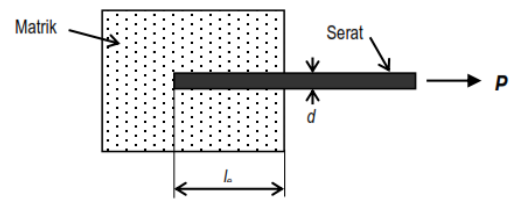

\section{Gambar 1. Mekanisme pull out (Nugraha, 2015)}

Gaya tarik longitudinal pada serat akan menghasilkan geser pada daerah interfase serat/matrik dan ketika serat tertarik lepas dari matrik maka terjadi tegangan geser interfacial antara serat-matrik. Kekuatan geser interfacial ditunjukan dengan persamaan II.4: (Nugraha, 2015)

$\tau \mathrm{i}=\frac{p}{\pi \cdot d \cdot d \theta}$

nilai ( $\tau$ i) ditentukan dari gaya yang menyebabkan debonding $(\mathrm{P})$, diameter serat $(\mathrm{d})$, dan panjang serat tertanam (le),

\section{Uji tarik serat tunggal}

Spesimen serat pandan duri tempelkan pada kertas kartas karton yang dibentuk sesuai setandar ASTM D3379 menggunakan lem. Lima set spesimen disiapkan. Alat uji tarik serat dikalibrasi terlebih dahulu. Sebelum diuji kertas dipotong pada bagian tengah terlebih dahulu. 
Pastikan grip tercekam dengan baik pada alat pencekam.

\section{METODE PENELITIAN \\ Variabel Penelitian}

Beberapa variabel yang diamati pada penelitian ini ada tiga jenis variabel, antara lain:: 1 Variabel Bebas

Variabel yang dipakai adalah serat tanpa diberi perlakuan perendaman dan serat diberi perlakuan perendaman selama $1,2,3$, dan 4 minggu.

2 Variabel Terikat

Variabel terikat yang digunakan adalah kekuatan tarik serat tunggal, tegangan geser, dan foto mikro.

\section{Variabel Terkontrol}

Variabel terkontrol yang digunakan antara lain, serat daun pandan duri yang digunakan sebagai penelitian, daun pandan diambil didesa Dombo kec. Sayung, kab. Demak, air laut sebagai bahan alkalisasi, air laut diambi dipantai Marina Semarang, proses alkalisasi dilakukan selama 4 minggu, dan ukuran panjang serat sesuai standar uji tarik ASTM D3379.

\section{Alat dan Bahan}

Peralatan utama yang dipakai dalam penelitian adalah:

1. Alat uji tarik serat tunggal

2. Mikroskop metalografi

Adapun peralatan pendukung lainnya untuk membuat spesimen uji tarik dan spesimen single fiber pull out yaitu antara lain : cetakan untuk pengujian pull out yang dibuat dari pipa ukuran 5/8 inchi, kertas karton duplex, kertas lakmus, lem kertas, lilin/malam, ember,pisau plastik, gunting/cutter, ampelas, grease, dan isolasi.

Bahan yang digunakan adalah:

1. Resin unsaturated polyester tipe 108

2. Katalis MEKPO (methyl ethyl ketone peroxide) dan aquadest.

3. Air laut

4. Serat daun pandan duri

\section{Diagram alir penelitian}

Diagram alir penelitian ditunjuka pada Gambar 1. Serat dipisahkan terlebih dahulu dari kulit daun pandan duri, selanjutnya serat direndam kedalam air laut dan sebagian tanpa perendaman. Kemudian dilakukan pengujian tarik serat tunggal dan uji pull-out dilakukan pada semua spesimen dan hasilnya diamati menggunakan mikroskop metalografi. hasil pengujian dianalisis kemudian ditarik kesimpulan.

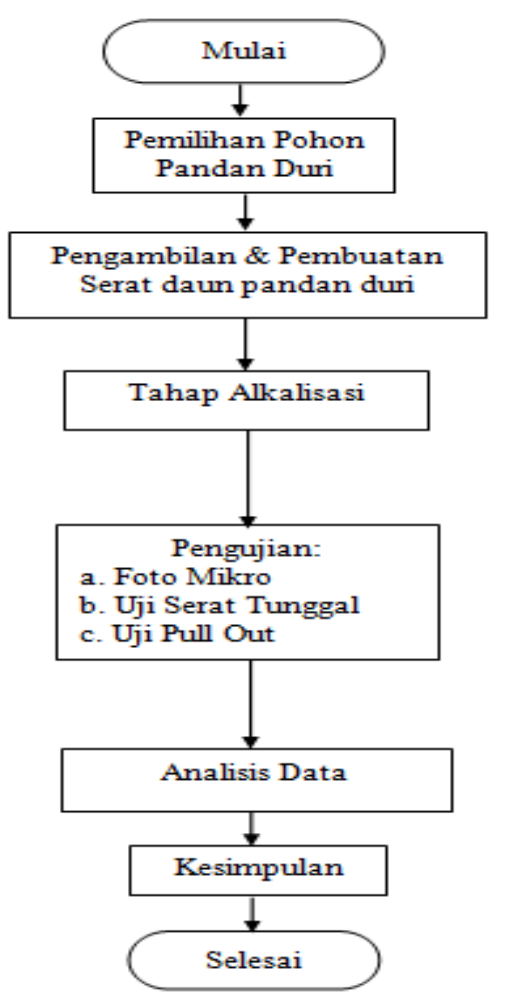

\section{Gambar 1. Diagram alir penelitian}

\section{HASIL DAN PEMBAHASAN \\ Hasil Pengujian Tarik Serat Tunggal}

Pengujian tarik serat tunggal pada serat daun pandan duri bertujuan untuk mengetahui kekuatan tarik maksimal, dari serat tanpa perendaman sampai dengan serat diberi perlakuan perendaman air laut yang memiliki nilai pH 7 selama 1, 2, 3, dan 4 minggu. Pada pengujian tarik serat tunggal diperoleh nilai beban dan regangan. Berdasarkan persamaan rumus 1 dan 2 maka diperoleh nilai tegangan tarik dan regangan sebagaimana pada Tabel 2, Gambar 2, 3 ,dan 4.

Tabel 2. Kekuatan tarik dan regangan serat

\begin{tabular}{|c|c|c|c|c|c|}
\hline $\begin{array}{l}\text { Waktu } \\
\text { perendaman } \\
\text { (minggu) }\end{array}$ & $\begin{array}{l}\text { Diameter } \\
\text { rata- rata } \\
(\mathrm{mm})\end{array}$ & $\begin{array}{l}\text { Beban } \\
\text { (F) } N\end{array}$ & $\begin{array}{l}\text { Luas } \\
\text { Serat } \\
\text { (A) } \\
\mathrm{mm}^{2}\end{array}$ & $\begin{array}{l}\text { Kekuatan } \\
\operatorname{tarik}(\sigma) \\
\mathrm{N} / \mathrm{mm}^{2}\end{array}$ & $\begin{array}{l}\text { Regangan } \\
\varepsilon(\%)\end{array}$ \\
\hline 0 & 0,55 & 3,24 & 0,24 & 13,39 & 2,69 \\
\hline 1 & 0,42 & 3,13 & 0,14 & 22,57 & 3,58 \\
\hline 2 & 0,40 & 3,51 & 0,12 & 28,66 & 4,03 \\
\hline 3 & 0,64 & 7,94 & 0,32 & 24,43 & 4,74 \\
\hline 4 & 0,79 & 9,29 & 0,49 & 18,96 & 4,90 \\
\hline
\end{tabular}


Pada hasil pengujian tarik serat tunggal daun pandan duri tanpa perlakuan memiliki kekuatan tarik sebesar 13,39 MPa, kemudian setelah dilakukan perlakuan perendaman air laut selama 1 minggu kekuatan tariknya meningkat sebesar 22,57 MPa. Dan kekuatan tarik serat tunggal tertinggi pada perendaman 2 minggu yaitu sebesar 28,65 $\mathrm{MPa}$, sedangkan pada minggu ke-3 kekuatan tarik serat tunggal menurun menjadi $24,43 \mathrm{MPa}$ dan pada perendaman 4 minggu kekuatan tarik serat tunggal semakin menurun menjadi 18,96 MPa.

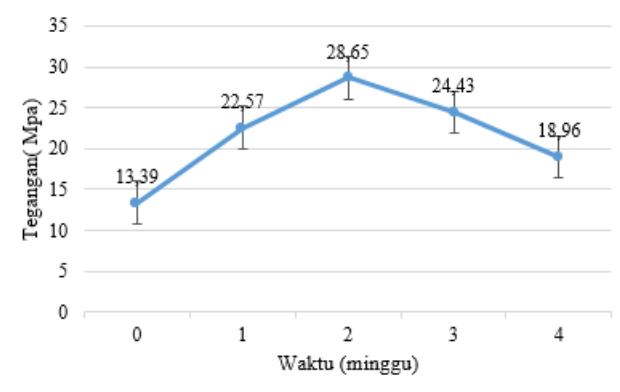

Gambar 2. Grafik pengaruh perendaman air laut terhadap tegangan tarik

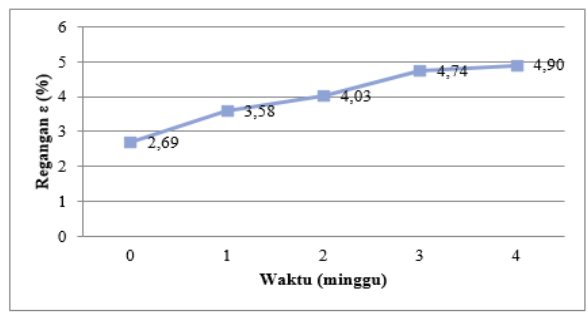

Gambar 3. Grafik pengaruh perendaman air laut terhadap regangan serat

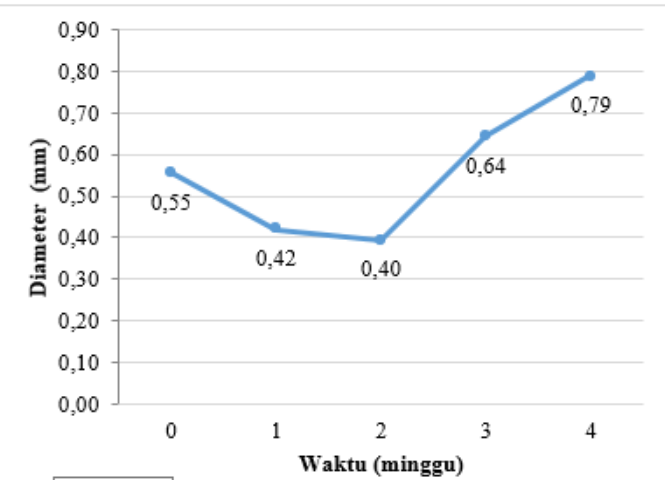

Gambar 4. Grafik pengaruh perendaman air laut terhadap diameter serat
Pada Gambar 2 merupakan hasil pengujian tarik serat daun pandan duri dengan perlakuan perendaman air laut menunjukkan bahwa perlakuan perendaman air laut dapat meningkatkan sifat mekanis kekuatan tarik. Tetapi lama waktu perendaman sangat berpengaruh pada kekuatan tarik serat karena semakin lama perendaman yang dilakukan maka tegangan pada serat semakin menurun disebabkan pada serat terlihat adanya celah antar sub serat dan diameter serat mengalami perubahan seperti yang ditunjukan pada Gambar 4. Hal ini sama yang disampaikan peneliti sebelumnya Agung (2016) yang menyatakan Perendaman meningkatkan kekuatan tarik tetapi semakin lama perendaman kekuatan tarik semakin menurun.

Pada Gambar 3 terlihat jelas pengaruh perendaman air laut terhadap serat pandan duri, semakin lama perendaman menggunakan air laut makan nilai regangan semakin tinggi. Hal ini sama seperti yang disampaikan Matasina dkk., (2014).

\section{Hasil Analisa Struktur Mikro Serat Pandan Duri}

Struktur mikro pada serat pandan duri tanpa perendaman air laut dapat yang ditunjukan pada Gambar 5 telihat struktur serat terlihat utuh tidak ada sub celah yang terlihat dan kulit serat tampak halus berwarna hijau.

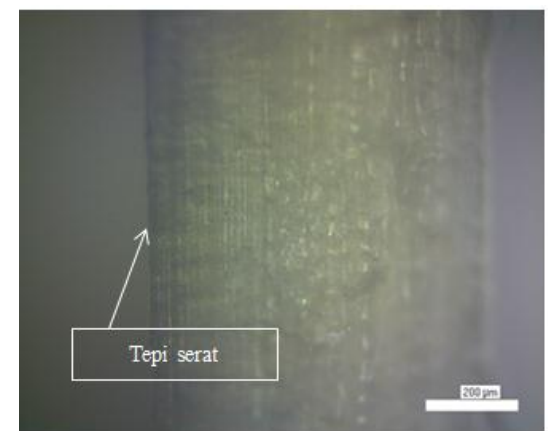

\section{Gambar 5.Foto mikro serat tanpa} perendaman air laut

Sedangkan dengan serat yang diberi perendaman air laut 1 minggu, 2 minggu, 3 minggu dan 4 minggu terlihat ada perubahan yang terjadi seperti pada Gambar 6. 

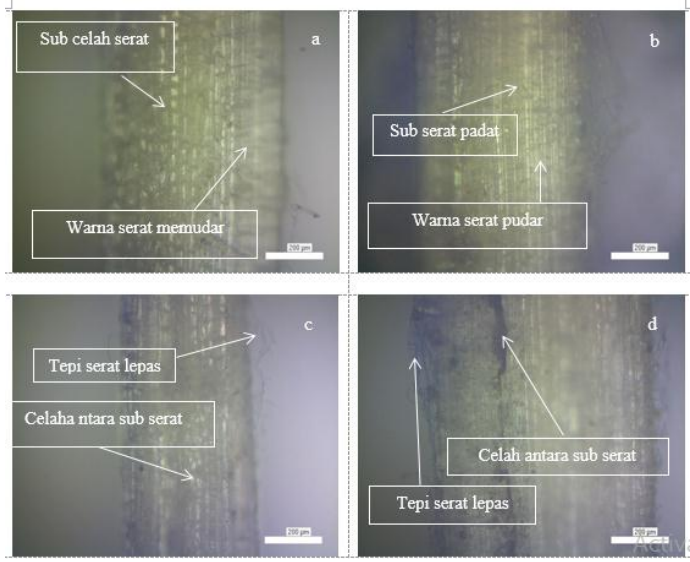

Gambar 6. Foto mikro serat daun pandan duri dengan perlakuan air laut, (a) perendaman 1 minggu, (b) perendaman 2 minggu, (c) perendaman 3 minggu, (d) perendaman 4 minggu

Pada Gambar 6 terlihat perubahan serat pandan duri dengan perlakuan perendaman air laut. Pada Gambar 6 (a) serat perendaman 1 minggu terlihat pada serat mengalami perubahan dari warna kulit yang memudar dan ada sub serat yang terlihat, kemudian pada minggu ke 2 dilihat pada Gambar IV.5 (b) menunjukan kepadatan sub celah dan warna kulit semakin pudar akibat meresapnya air laut kedalam serat yang signifikan. sedangkan pada Gambar IV.5 (c) terlihat adanya celah diantara sub serat dan sub serat ditepi serat mulai melepas, pada minggu ke 4 perendaman air laut dilihat pada Gambar IV.4 (d) warna dari kulit serat tampa pucat dan celah antara sub serat yang besar diikuti dengan sub serat ditepi serat terlihat lepas. Hal ini menujukan bahwa semakin lama perendaman akan semakin besar celah antar sub serat sehingga terjadi pembesaran diameter yang dikarenakan banyak air yang diserap atau yang masuk ke dalam serat dan warnanya yang awalnya hijau semakin lama menjadi pucat.

\section{Hasil Pengujian Single Fiber Pull-out}

Dari pengujian diperoleh data seperti pada Tabel 5 Interfacial Shear Stress (IFSS)
Tabel 5. Tegangan Geser tiap perlakuan

\begin{tabular}{cccc}
\hline $\begin{array}{c}\text { Waktu } \\
\text { (Minggu) }\end{array}$ & $\begin{array}{c}\text { Panjan Serat } \\
\text { Tertanam le (mm) }\end{array}$ & $\begin{array}{c}\text { Diameter Serat } \\
(\mathrm{mm})\end{array}$ & $\begin{array}{c}\text { Tegangan } \\
\text { Geser }(\mathrm{MPa})\end{array}$ \\
\hline 0 & 1 & 1,50 & 0,88 \\
1 & 1 & 0,75 & 1,11 \\
2 & 1 & 0,67 & 1,33 \\
3 & 1 & 1,02 & 1,21 \\
4 & 1 & 1,10 & 1,12 \\
\hline
\end{tabular}

Kekuatan geser interfacial ( $\tau i$ ) antara serat daun pandan duri-resin poliester yang tampak pada Gambar 6 membuktikan bahwa terjadi penambahan kekuatan geser interfacial yang disebabkan perlakuan perendaman serat menggunakan air laut. Kekuatan geser interfacial perlakuan perendaman air laut memiliki nilai tertinggi pada perendaman selama 2 minggu dengan nilai sebesar 1,33 Mpa dibanding tanpa perlakuan dan perlakuan perendaman selama 1 minggu yaitu 1,09 Mpa dan 1,11 Mpa. Kekuatan geser interfacial tertinggi pada perendaman 2 minggu, dikarenakan pada waktu 2 minggu air laut terdifusi kedalam serat secara signifikan, sehingga sub serat menjadi padat, maka terjadi ikatan yang semakin kuat antara matrik dengan serat.

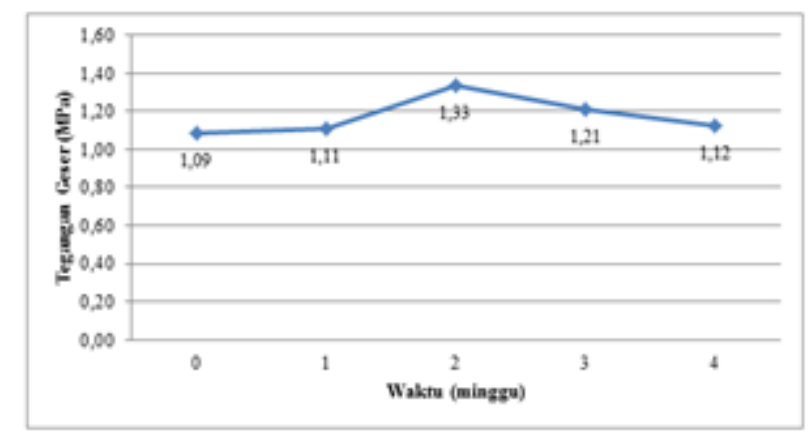

\section{Gambar 6. Grafik pengaruh perendaman air laut terhadap tegangan geser interfacial}

Sedangkan pada perendaman selama 3 dan 4 minggu kekuatan geser interfacial terjadi penurunan dengan nilai 1,21 Mpa dan 1,07 Mpa, hal ini disebabkan karena pengaruh lama waktu perendaman serat menggunakan air laut, sehingga semakin besar celah antara sub serat yang membuat kekuatanya rendah, rapuh dan mudah patah. Sama seperti peneliti sebelumnya (Fattah dkk, 2013). 


\section{Hasil foto makro}

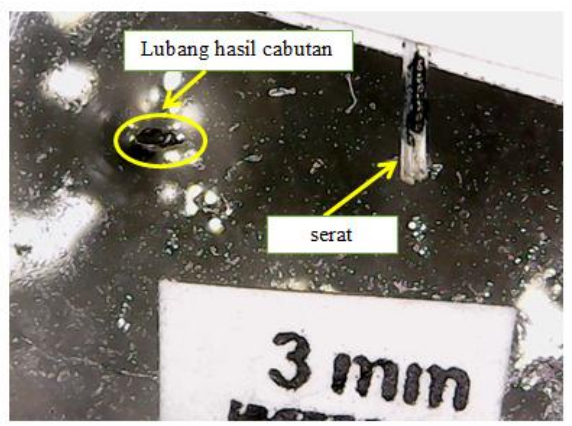

\section{Gambar 7. Hasil uji pull out serat pandan duri tanpa perendaman}

Pada Gambar 7 menunjukkan serat hasil cabutan uji pull out serat yang tanpa perendaman air laut. Lubang hasil cabutan tidak mengalami kerusakan. Hal ini dikarenakan serat tanpa perendaman mempunyai kulit yang menutupi serat pada permukaannya yang membuat resin tidak bisa menepel dengan sempurna pada serat, sehingga nilai tegangan gesesmya sangat kecil.

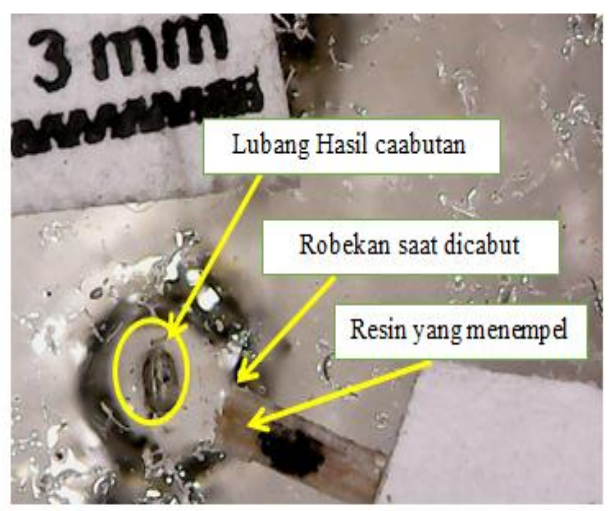

\section{Gambar 8. Hasil uji pull out serat pandan duri perendaman 1 minggu}

Pada Gambar 8 hasil cabutan terlihat pada tepi lubang cabutan tidak ada serat yang tertinggal, tetapi ada robekan dibagian ujung serat yang dikarena proses tarikan serat dengan resin. Ini menandakan sedikitnya kompatibilitas antara resin dengan serat terlihat sedikit resin yang menempel pada serat yang tercabut dan nilai dari tegangan interfacial mulai meningkat.

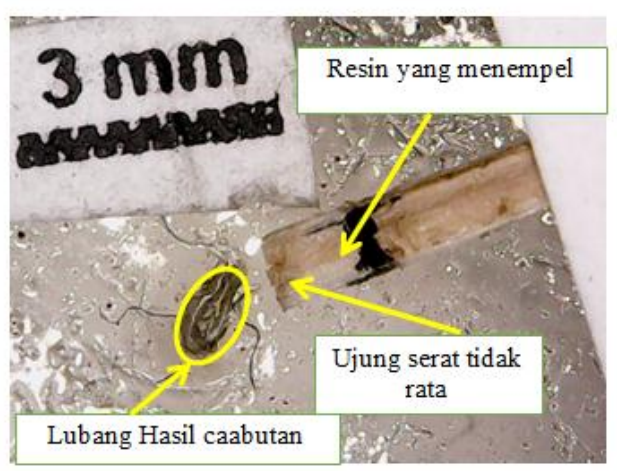

\section{Gambar 9 Hasil uji pull out serat perendaman air laut 2 minggu}

Gambar 9 merupakan hasil uji pull out pada perendaman air laut 2 minggu, terlihat jelas adanya sedikit lapisan serat yang tertinggal di lubang hasil cabutan, terlihata pada ujung serat tertanam tampak tidak rata, tetapi serat yang tertanam tidak adanya kerusakan pada permukaan serat, hal ini menandakan adanya Kompatibilitas yang sangat kuat antara serat dengan resin. Pada uji pull out serat perendaman air laut selama 2 minggu memiliki nilai tegangan geser yang paling tinggi, terlihat dari serat yang tertanam terdapat resin yang menempel cukup banyak yang membuat kekuatan tariknya tinggi dan membuat tegangan tegeser interfacial menjadi tinggi.

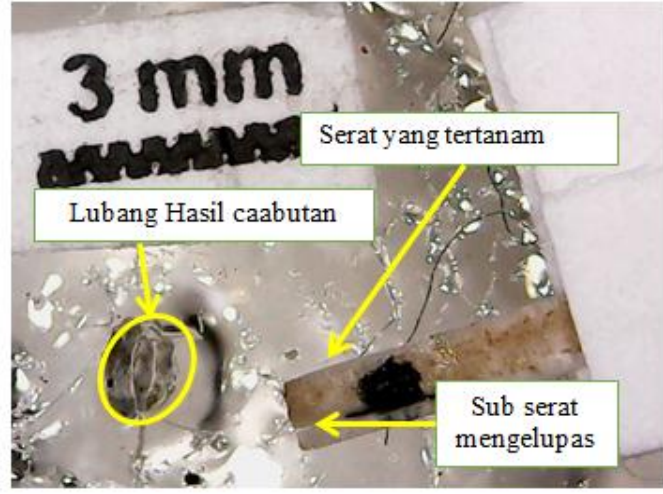

\section{Gambar 10 Hasil uji pull out serat perendaman air laut 3 minggu}

Pada Gambar 10, terlihat serat hasil cabutan mengalami kerusakan dengan terlihatnya sub serat yang mengelupas, pada serat yang ditanam terdapat resin yang menepel, dan ujung serat menyusut karena proses perendaman air laut dan uji tarik antara serat dan resin tersebut. Hal ini menyebabkan tegangan geser interfacial menurun. Sedangkan pada lubang hasil cabutan 
tidak ada serat yang tertinggal dan serat yang tertanam dapat tercabut sempurna.

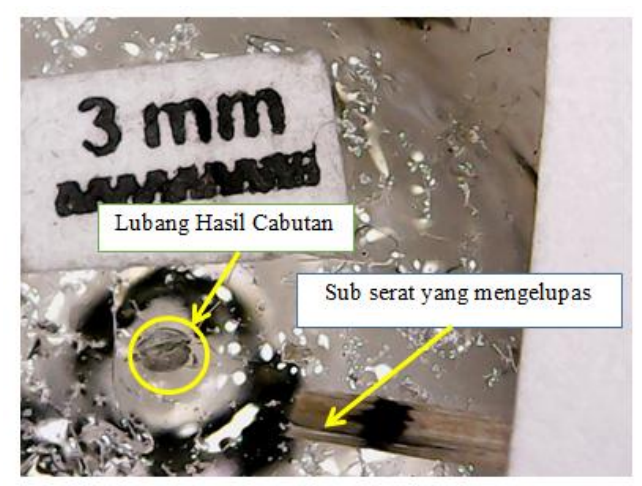

\section{Gambar 11 Hasil uji pull out serat perendaman air laut 4 minggu}

Sedangkan pada Gambar 11 adalah hasil dari pengujian pull out serat perendaman air laut dengan waktu perendaman 4 minggu. Pada lubang hasil cabut tidak terdapat serat yang tertinggal namun serat tampak rusak karena sub serat yang mengelupas memanjang, menyebabkan nilai tegangan geser interfacial menurun.

\section{Hasil Foto Mikro Kerapatan Serat Daun Pandan Duri Dengan Resin}

Uji kerapatan serat daun pandan duri menggunakan alat mikroskop metalografi untuk mengetahui kompatibilitas antara serat dengan resin bagus atau kurang, serat tanpa diberi perlakuan perendaman air laut maupun yang sudah diberi perlakuan perendaman selama 1 minggu, 2 minggu, 3 minggu dan 4 minggu.

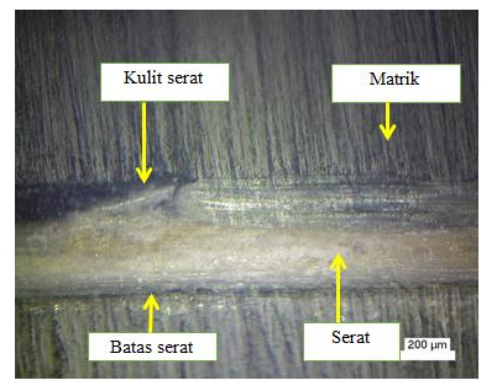

\section{Gambar 12 Kerapatan serat tanpa perendaman air laut}

Pada gambar terlihat batas serat dan matriknya, belum terlihat adanya resin yang masuk kedalam serat tersebut, karena serat tanpa perendaman masih terdapat adanya kulit serat yang ada pada permukaan serat, sehingga membuat resin tersebut sulit untuk menempel.

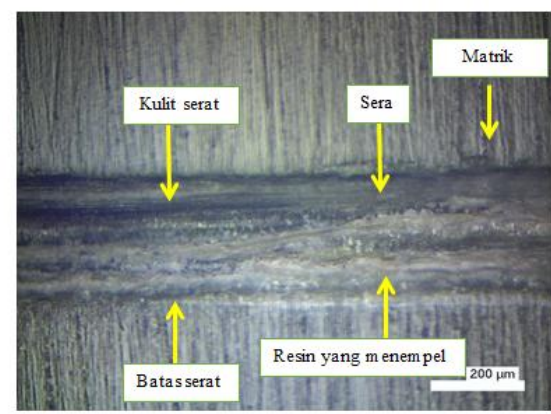

\section{Gambar 13 Kerapatan serat perendaman air laut 1 minggu}

Untuk perendaman 1 minggu menggunakan air laut pada uji mikro gambar kerapatan serat dapat dilihat pada Gambar 13, dari gambar terlihat serat daun pandan duri pada perendaman minggu masih terlihat berkurangnya kulit serat yang menempel dan sudah terlihat sedikit resin yang menempel pada serat. Hal ini menyebabkan pada perendaman 1 minggu serat dalam air laut tegangan gesernya mulai naik.

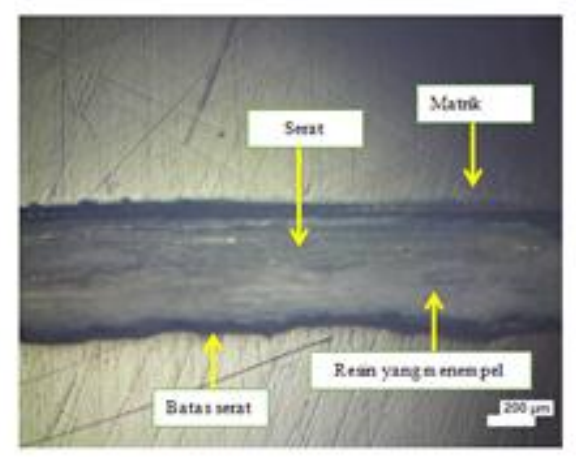

\section{Gambar 14 Kerapatan serat perendaman air laut 2 minggu}

Selanjutnya Pada Gambar 14 kerapatan serat perendaman air laut dengan waktu 2 minggu. Menunjukan adanya resin yang masuk ke serat tersebut karena hilangnya kulit serat yang ada pada permukaan serat tersebut dan pada batas serat tampak tidak rata. Hal ini yang membuat nilai tegangan geser mempunyai nilai tertinggi, karena kompatibilitas antara serat dengan matriknya sangat bagus dengan adanya resin yang menepel pada bagian tengah pada serat. 


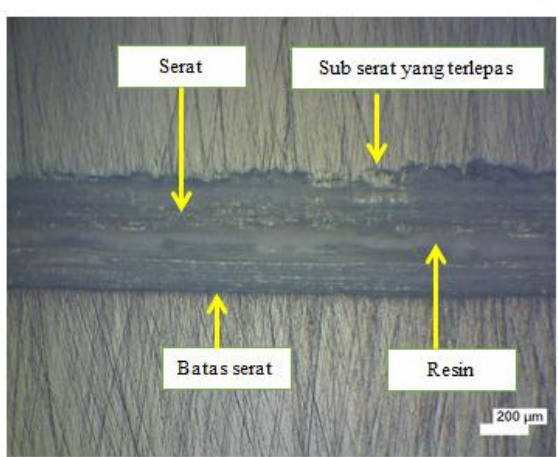

\section{Gambar 15 Kerapatan serat perendaman air laut 3 minggu}

Kemudian serat perendaman air laut selama 3 minggu mempunyai hasil seperti yang ditunjukan pada Gambar 15. Pada gambar terlihat jelas mana batas serat dengan matriknya, adanya resin yang menempel pada serat, dan tepi serat tampak sub serat yang terlepas, hal ini dikarenakan akibat lama rendaman air laut selama 3 minggu, sehingga membuat tegangan geser menjadi menurun dan membuat serat menjadi rusak.

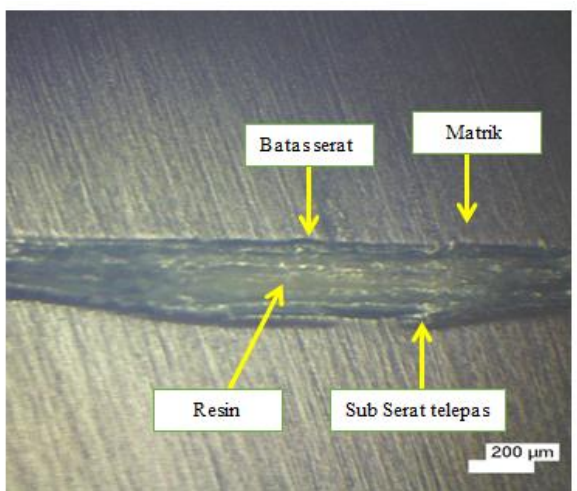

\section{Gambar 16 Kerapatan serat perendaman air laut 4 minggu}

Sedangkan dari Gambar 16 menunjukan hasil kerapatan serat perendaman air laut selama 4 minggu, terlihat jelas pada tepi serat mengalami kerusakan, banyaknya resin yang menempel pada serat, dan dan serat yang mengalami penyusutan akibat perendaman air laut selama 4 minggu. Hal ini membuat tegangan geser menjadi menurun disebabkan semakin lamanya perendaman air laut pada serat membuat tegangan geser menjadi menurun dan membuat serat menjadi rusak.

\section{KESIMPULAN} bahwa:
1) Perlakuan perendaman air laut dapat meningkatkan sifat mekanis kekuatan tarik, tetapi lama waktu perendaman kekuatan tarik akan mengalami penurunan. Hasil dari pengujian tarik serat tunggal daun pandan duri tanpa perlakuan perendaman air laut memiliki nilai kekuatan tarik 13,39 Mpa, dan kekuatan tarik tertinggi terjadi pada perlakuan perendaman 2 minggu yaitu sebesar 28,65 Mpa, sedangkan pada waktu perendaman 3 dan 4 minggu kekuatan tariknya menurun menjadi 24,43 $\mathrm{MPa}$ hingga 18,96 MPa, hal tersebut disebabkan terjadinya penyerapan air laut kedalam serat, sehingga diameter serat mengalami penambahan yang signifikan. Pada analisa struktur mikro terjadi perubahan kararteristik permukaan serat antara serat tanpa perlakuan perendaman dengan perlakuan perendaman air laut, mulai dari warna serat yang berubah hingga terlihat celah antara sub seratnya.

2) Serat daun pandan duri mempunyai kompatibilitas yang sangat bagus dengan resin polyester, karena hasil dari pengujian Pull Out dan kerapatan serat dan matrik, serat yang direndaman air laut selama 2 minggu mempunyai nilai tegangan geser 1,33 Mpa, dikarenakan pada serat perendaman 2 minggu memiliki ikatan yang bagus antara serat dan resin, seperti hasil foto mikro kerapatan serat perendaman air laut 2 minggu yang menunjukan adanya resin yang masuk ke serat tersebut karena hilangnya kulit serat yang ada pada permukaan serat tersebut dan pada batas serat tampak tidak rata.

\section{DAFTAR PUSTAKA}

Estiasih, T. D. (2009). Teknologi Pengolahan Pangan. Bumi Aksra. Jakarta.

Fattah, A. R. (2013). Pengaruh Bahan Kimia dan Waktu Perendaman terhadap Kekuatan Tark Bambu Betung (Dendrocalamus Asper) sebagai perlauan kimia. Institut Teknologi, Sepuluh November

Mardin.H. (2014). Pengaruh Permukaan Serat Kelapa Sawit Terhadap Bonding Interfasial Dengan Matrik Sagu. Department of Mechanical Engineering, Universitas Muslim Indonesia.

Nugraha, I.P., 2015 "Pengaruh Perlakuan Alkali Terhadap Kekuatan Tarik dan Geser Interfacial Serat Alam Rami-Resin Epoxy." 
Proceeding Seminar Nasional Tahunan Teknik Mesin XIV ,: 2-4.

Salahudin, X. (2012). Kaji Pengembangan Serat Daun Pandan Kab Magelang Sebagai Bahan Komposit Interior Mobil. Fakultas Teknik Universitas Tidar Magelang.

Smith F. W. (1986). Principles Of Matrials Science And Engineering. Univ. Of Central Florida.

Winarni, I. d. (2006). Penningkatan Teknik Pengolahan Pandan (Bagian I) Pewarnaan Dan Pengeringan. Journal of Chemical. 